\title{
General and specific combining abilities in a lulo diallel cross (Solanum quitoense Lam.)
}

\section{Aptitud combinatoria general y especifica en un dialelico de lulo (Solanum quitoense Lam.)}
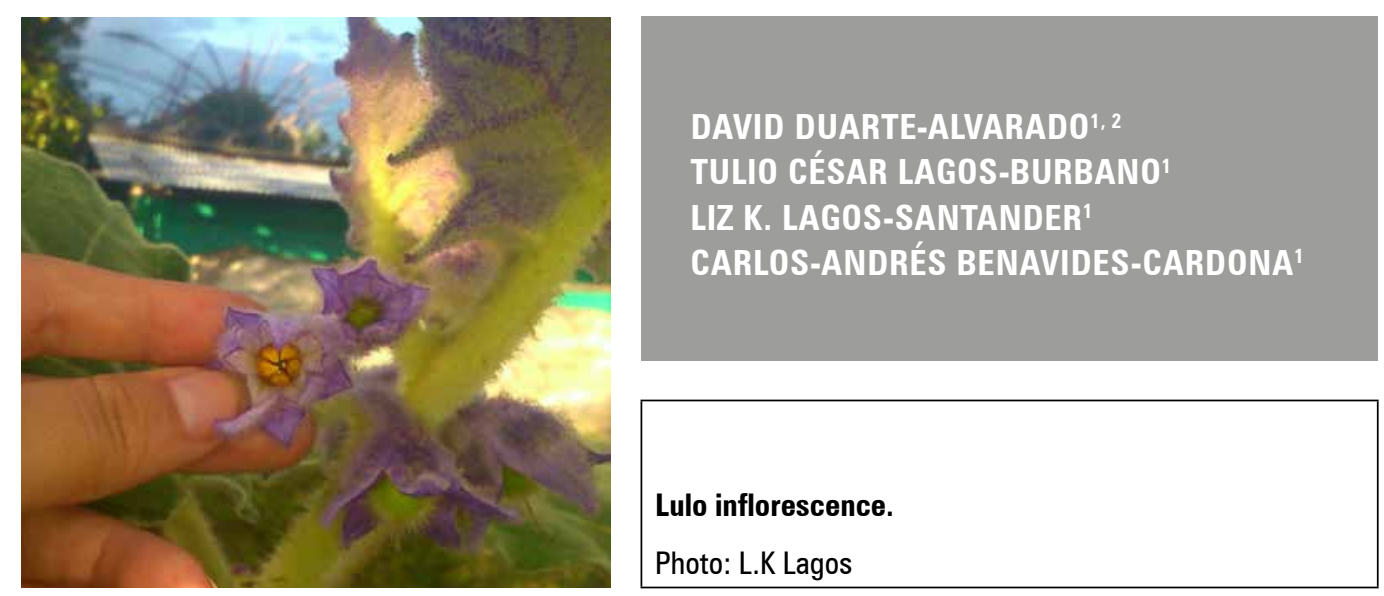

\begin{abstract}
Lulo (Solanum quitoense) is a promising agro-industry fruit tree, not only because of its nutritional value, taste, and appearance but also because it provides an alternative production system in mild and moderately cold climate zones. Lulo crop yield and production in the Department of Nariño (Colombia) has decreased in recent years when compared to other producing regions in Colombia. Therefore, the objective of this study was to estimate the effects of the general combining ability (GCA) and the specific combining ability (SCA) in a diallel cross of 10 promising parents in four growing regions of the Department of Nariño for use in breeding programs. A total of 45 hybrid combinations were obtained and assessed with Griffing method 4 . The following variables were assessed: days to flowering onset (DFO), number of clusters per branch (NCB), fruit weight (FW), polar axis (PA) of the fruit, and yield (Y). The analysis of variance showed statistical differences for most variables in response to single-cross hybrid effects and locations, except for NCB and Y. Moreover, significant differences were found for the interactions between the GCA and SCA and the hybrids and locations, respectively, meaning that environment must be considered when selecting parents with specific adaptability. The effects of the GCA and SCA promoted higher positive values for the FW and Y in parents 4, 6 , and 8 and their combinations. Therefore, these parental genotypes are promising for lulo genetic improvement programs since their additive effects and genetic dominance favor fruit weight and yield.
\end{abstract}

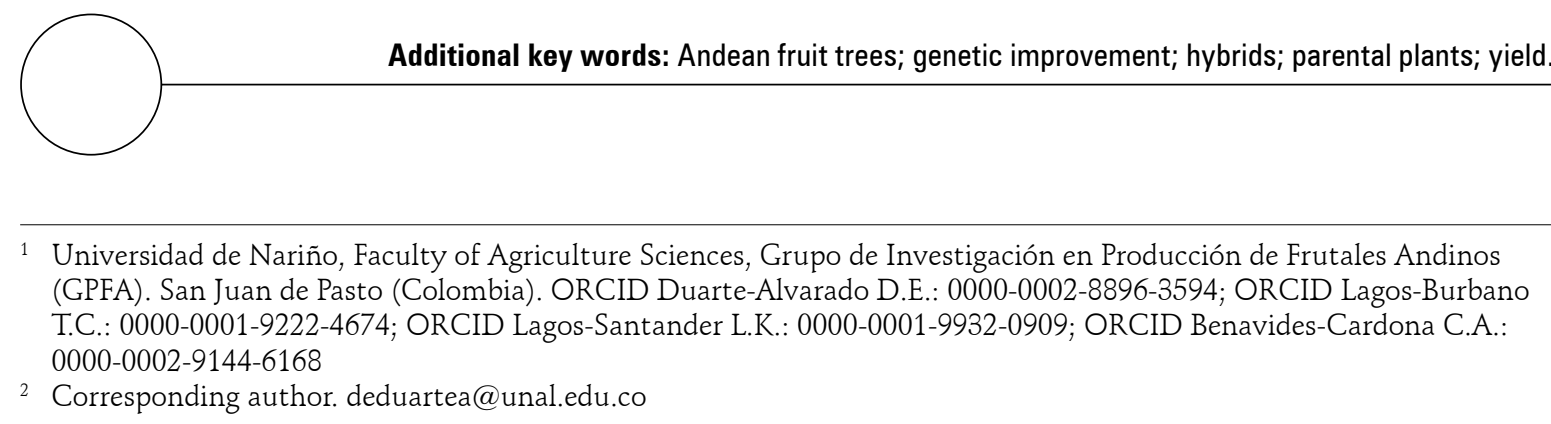




\section{RESUMEN}

El lulo (Solanum quitoense) es un árbol frutal prometedor para la agroindustria, no sólo por su valor nutritivo, su sabor y su aspecto, sino también porque constituye un sistema de producción alternativo en zonas de clima templado y moderadamente frío. El rendimiento de los cultivos y la producción de lulo en el Departamento de Nariño (Colombia) han disminuido en los últimos años en comparación con otras regiones productoras del país. Por lo tanto, el objetivo de este estudio fue estimar los efectos de la habilidad combinatoria general (HCG) y la habilidad combinatoria especifica (HCE) en un cruzamiento dialelico de 10 progenitores promisorios en cuatro regiones del Departamento de Nariño, que pueden considerarse en los programas de mejoramiento. Se obtuvieron un total de 45 combinaciones híbridas obtenidas con el método 4 de Griffing. Se evaluaron las siguientes variables: días para el inicio de la floración (DIF), número de racimos por rama (NRR), peso del fruto (PF), eje polar (EP) del fruto y rendimiento (RTO). El análisis de la varianza mostró diferencias estadísticas para la mayoría de las variables en respuesta a los efectos de los híbridos y a las localidades, excepto para NRR y RTO. Además, se encontraron diferencias significativas para las interacciones del HCG y HCE con los híbridos y las localidades, respectivamente, demostrando que debe considerarse el medio ambiente para seleccionar los progenitores con una adaptabilidad específica. Los efectos del HCG y HCE presentan valores positivos altos para PF y RTO en los parentales 4, 6 y 8 y en sus combinaciones. Por lo tanto, estos parentales son promisorios para los programas de mejoramiento genético del lulo, ya que sus efectos aditivos $y$ de dominancia favorecen el peso y el rendimiento del fruto.

Palabras clave adicionales: frutales andinos; mejoramiento genético; híbridos; parentales; rendimiento.

Received: 28-10-2020 Accepted: 25-11-2020 Published: 13-01-2021

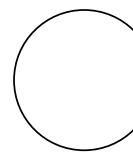

\section{INTRODUCTION}

The lulo (Solanum quitoense Lam.) is a fruit tree species in the Solanaceae family, and is a promising crop for agro-industry because of its potent organoleptic characteristics and physical traits (Cardona et al., 2016; Criollo-Escobar et al., 2020). It is an economically important crop in Colombia, mainly in the Andean region (Almanza-Merchán et al., 2016; Sánchez-Reinoso et al., 2019).

In Colombia, this crop is grown between 1,300 and 2,200 $\mathrm{m}$ a.s.1. mainly using two species: S. quitoense var. quitoense (sweet and without thorns) and $S$. quitoense var. septentrionale (acid and with thorns) (Ochoa-Varagas et al., 2016). In 2018, there were approximately 8,800 ha of this crop established in 21 departments, particularly Huila and Valle del Cauca, which had the larger crop areas, covering 2,005 and 1,029 ha, respectively. The domestic lulo production increased from 8.87 to $9.86 \mathrm{t} \mathrm{ha}^{-1}$ in the last 10 years (Agronet, 2020).

In 2018, the Department of Nariño had 609 ha of lulo crops according to Agronet (2020), mainly distributed across the northern and southern municipalities. This crop area produced an average yield of 5.64 t ha ${ }^{-1}$; accordingly, Nariño ranked fourth for the domestic supply and had a yield deficit (i.e., lower yield than the national average). Moreover, departments such as Huila (7.15 $\left.\mathrm{t} \mathrm{ha}^{-1}\right)$ and Valle del Cauca (12.2 t $\left.\mathrm{ha}^{-1}\right)$ had larger crop areas and production.

One of the main factors limiting lulo cultivation in Colombia is the insufficient supply of improved cultivars, mainly the result of the scarcity of genetic improvement plans or programs for this species. There are no medium- and long-term solutions, making it necessary to generate strategies to increase productivity. One of these strategies is the evaluation of the germplasm with different approaches (LagosSantander et al., 2019). In these evaluations, a population analysis can be used to study the genetic control of quantitative traits, evaluating both general and specific combinatorial skills in breeding programs to obtain desired agronomic and genetic traits, depending on the research context (Manjarrez et al., 2014).

In Colombia, studies on lulo have focused on the germplasm that has been collected and conserved, especially in the departments of the Andean region. This research has allowed advancements in 
the characterization, assessment, and enhancement of the variability in this species. For instance, lulo La Selva is an improved cultivar with traits such as lack of thorns, erect growth habit, and high fruit set, among others (Medina et al., 2009). Furthermore, studies by Morillo-Coronado et al. (2017) and Morillo et al. (2019) reported genetic diversity in lulo plants from the central region of Colombia.

When genetic improvement programs focus on hybridization, the genetic performance of economically important traits in each population must be elucidated, as well as the type of gene action in relevant traits. This will enable the selection of the best improvement scheme for maximizing genetic variance, such as increasing and fixing the frequencies of desirable genes in a population (Luna et al., 2013; Haochuan et al., 2014).

A proposed method evaluates the general combinatorial ability (GCA) and specific combinatorial ability (SCA), conceptually defined by Sprague and Tatum (1942): the GCA is the average yield of a line in all its hybrid combinations and the SCA applies to cases in which specific hybrid combinations are expressed positively or not, compared with the average yield of the parents. The GCA and SCA were evaluated using four methods developed by Griffing (1956), which are based on the analysis of the parents and their direct and reciprocal F1 crosses (1); the parents and their direct F1 crosses (2); the direct and reciprocal F1 crosses (3); and only the direct F1 crosses (4).

According to Cervantes et al. (2011), the evaluation of germplasm with these methods first take advantage of the additive genetic variance by selecting parents with good GCA and then the non-additive variance with hybridization in the crosses with good SCA. These parallel analyses estimate the genetic parameters of the parents and their progeny to determine the most appropriate method of genetic improvement (Wong et al., 2007). A single cross has a high yield when both parents have a high GCA or at least one line has a high GCA and positive SCA effects (Escorcia-Gutiérrez et al., 2010; Guerrero-Guerrero et al., 2011). Lines with high GCA effects can be used to develop synthetic varieties, while specific combinations with high yield are used in hybridization schemes. In addition, the effects caused by GCA are associated with additive effects in genetic improvement and can be used for the selection and subsequent hybridization of progenitors with good combining ability (Cervantes-Ortiz et al., 2016).
In lulo crops, there are several baseline studies for the establishment of improvement programs based on the assessment of genetic effects to select individuals with high desirable traits. For instance, Lagos et al. (2015) assessed the performance of half-sibling families to obtain cultivars with better fruit quality for specific markets. Furthermore, Lagos-Santander et al. (2020) reported differences in the fruit quality and yield of parents and lulo hybrids in the Department of Nariño.

This study aimed to determine the genetic components of the GCA and SCA involved in growth, development, and fruit quality variables in a diallel cross of 10 parents from half-sibling families of lulo in four growing regions in the Andean region of the Department of Nariño (Colombia).

\section{MATERIALS AND METHODS}

This research was conducted on farms located in four municipalities in the Andean region of the Department of Nariño (Colombia): Tangua, Arboleda, San Pedro de Cartago, and La Union. In Tangua, the experimental plot was located at $1^{\circ} 3^{\prime} 44,74^{\prime \prime} \mathrm{N}$, $77^{\circ} 25^{\prime} 12,26^{\prime \prime} \mathrm{W}$, with an altitude of $2,403 \mathrm{~m}$ a.s.l., an average temperature of $16^{\circ} \mathrm{C}$ and sandy clayloam soil. The plot in Arboleda was at 1 ${ }^{\circ} 30^{\prime} 45^{\prime \prime} \mathrm{N}$, $77^{\circ} 08^{\prime} 42^{\prime \prime}$ W, $2100 \mathrm{~m}$ a.s.l., with an average temperature of $19^{\circ} \mathrm{C}$ and clay soil. The plot in San Pedro de

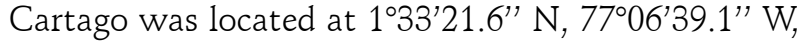
with an altitude of $2,100 \mathrm{~m}$ a.s.1. and $18^{\circ} \mathrm{C}$ temperature in a sandy clay soil, and the plot in La Union was situated at $1^{\circ} 34^{\prime} 12.1^{\prime \prime} \mathrm{N}, 77^{\circ} 07^{\prime} 36.9^{\prime \prime} \mathrm{W}$, with an average temperature of $19^{\circ} \mathrm{C}$, an altitude of $1650 \mathrm{~m}$ a.s.l. and clay soil.

A diallel cross with 10 parents from half-sibling families (HSF) of lulo was conducted to obtain an F1 cross comprising 45 hybrids. The plants were obtained from the Grupo de Investigación en Producción de Frutales Andinos (GPFA) of Universidad de Nariño. The parents had desirable agronomic characteristics, with yields ranging from 5.08 to $10.21 \mathrm{t} \mathrm{ha}^{-1}$, fruit weight varying from 63.4 to $78.87 \mathrm{~g}$ and total soluble solids ranging from 9.41 to $10.72^{\circ} \mathrm{Bx}$. The diallel cross was done with Griffing method 4, which included direct F1 crosses and excluded parents and reciprocal crosses.

An alpha-lattice experiment design with two repetitions was used at each location. The repetitions comprised 45 treatments on the lulo hybrids from 
the diallel cross. Each treatment was performed on a row of five plants, with $2.5 \mathrm{~m}$ between plants and 3.0 $\mathrm{m}$ between rows, for a total of 90 experiment units. Two border rows with 20 plants each were planted on each side of the experimental plots, for a total of 470 plants per experiment, covering a surface area of $3,525 \mathrm{~m}^{2}$. The useful plot included three central plants in an area of $22.5 \mathrm{~m}^{2}$.

The assessed variables included: days to flowering onset (DFO), determined as the number of days from the beginning of the experiment until the onset of flowering in $50 \%$ of the experimental plot; number of clusters per branch (NCB), determined as the number of floral clusters in three productive branches per plant in the experimental plot; fruit weight (FW), determined as the average weight of five fruits per introduction (g); polar axis of the fruit (PA), determined as the average polar axis length of five fruits (the measurements were taken using a caliper, $\mathrm{mm}$ ), and yield $(Y)\left(t h^{-1}\right)$, determined based on the weight of fruits harvested from the useful plot (three central plants) for six months during the production phase. The fruits were harvested at maturity stage 3 (ICONTEC, 2002).

The experiment data were analyzed using an analysis of variance (ANOVA) with SAS (System of Statistical Analysis) version 9.0. Significant differences between treatments were established when the null hypothesis was rejected for a given variable, as reported by Antuna et al. (2003) and De la Cruz et al. (2010). These authors established significant differences between treatments when the highest values were greater than the overall mean plus the standard error $(\mu+\sigma)$ and highly significant when the values were greater than the mean plus twice the standard error $(\mu+2 \sigma)$. For the DFO, the potent hybrids had values below $\mu-\sigma$ or $\mu-2 \sigma$, indicating significant or highly significant differences.

The sum of squares for the hybrids and hybrids $\mathrm{x}$ locations were separated by the GCA and SCA (as sources of variation), as well as the interactions of the combining abilities with the locations-L (i.e., GCA $\times$ L and SCA $\times$ L, respectively). The effects were calculated using the GENES software (Cruz, 2006).

\section{RESULTS AND DISCUSSION}

The mean of the squares for the combined ANOVA showed a significant effect from the locations $(P<0.01)$ for all variables (Tab. 1$)$. This effect can be attributed to environmental components such as the soil type and climate. The interaction $\mathrm{H} \times \mathrm{L}$ was highly significant $(P<0.01)$ for the DFO, NCB, FW, and $Y$. The hybrids showed highly significant differences $(P<0.01)$ in DFO and PA, along with significant differences $(P<0.05)$ for FW. Accordingly, De la Cruz et al. (2007) stated that significant effects might result from differences between hybrids because of the sum of the additive effects of their parents, making it possible to select the best hybrids. However, there were no significant differences in NCB and Y, likely indicating that these traits are strongly influenced by the environment (Camposeco et al., 2015).

There were significant differences in DFO and PA in response to the GCA effects. Specifically, these variables showed a higher mean of squares than those obtained for the SCA, indicating that additive genetic variation determines the response of these two variables more than non-additive variation (Ortiz and Rodes, 1993). Conversely, there were no significant differences in the NCB, FW, Y, or SCA (Tab. 1). Similar results were found by Lagos et al. (2007) in a dialelic of 10 Physalis peruviana parents, where SCA was not significant for yield.

For the interactions between GCA $\times \mathrm{L}$ and $\mathrm{SCA} \times \mathrm{L}$ and the variables $\mathrm{DFO}, \mathrm{NCB}, \mathrm{FW}$, and $\mathrm{Y}$ showed highly significant differences $(P<0.01)$, indicating distinct performances of each parent and hybrid across the environments. Therefore, parents with significant GCA effects across environments should be selected (De la Rosa et al., 2000). For the DFO, NCB, and Y, the contribution of the effects of GCA $\times \mathrm{L}$ was greater than that of the effects of SCA $\times$ L. This finding demonstrates that additive effects dominate over nonadditive effects. For the PA, the interactions between $\mathrm{GCA} \times \mathrm{L}$ and $\mathrm{SCA} \times \mathrm{L}$ were non-significant, indicating that the hybrids may be stable across the evaluated environments and that the expression of AP is not defined by this factor but by genotype. From this point of view, it is possible to select hybrid combinations with significant AP averages with the expectation that they will be stable or that their average improves when the environment offers better conditions for the expression of this characteristic (Tab. 1).

Overall, the additive effects dominated the nonadditive effects for the assessed traits. This result indicates that the selection of parents with good characteristics for $\mathrm{DFO}, \mathrm{NCB}$, and $\mathrm{Y}$ can increase the productive potential species according to the significant environmental effect (Tab. 1) (Vivek et al., 2010). 
Table 1. Mean of squares of the combined analysis of variance for performance traits in 45 lulo (S. quitoense) hybrids assessed in four locations in the Andean region of the Department of Nariño.

\begin{tabular}{|l|c|c|c|c|c|c|}
\hline \multicolumn{1}{|c|}{ SV } & DF & DF0 & NCB & PA & FW & Y \\
\hline LOCALITY (L) & 3 & $12081.27^{* *}$ & $1390.50^{* *}$ & $1618.70^{* *}$ & $10546.95^{* *}$ & $5823.28^{* *}$ \\
\hline REP(L) & 4 & $265.82^{* *}$ & $0.82^{\text {NS }}$ & $38.76^{* *}$ & $1.74^{\text {NS }}$ & $1.86^{\text {NS }}$ \\
\hline HYBRID (H) & 44 & $185.98^{* *}$ & $6.92^{\text {NS }}$ & $16.84^{* *}$ & $589.37^{*}$ & $26.35^{\text {NS }}$ \\
\hline GCA & 9 & $512.25^{*}$ & $10.03^{\text {NS }}$ & $36.13^{* *}$ & $678.83^{\text {NS }}$ & $27.77^{\text {NS }}$ \\
\hline SCA & 35 & $102.08^{\text {NS }}$ & $6.12^{\text {NS }}$ & $11.88^{\text {NS }}$ & $566.37^{\text {NS }}$ & $25.99^{\text {NS }}$ \\
\hline H $\times \mathrm{L}$ & 132 & $98.68^{* *}$ & $5.44^{* *}$ & $8.13^{\text {NS }}$ & $385.97^{* *}$ & $24.71^{* *}$ \\
\hline GCA $\times L$ & 27 & $167.30^{* *}$ & $7.72^{* *}$ & $7.72^{\text {NS }}$ & $360.71^{* *}$ & $25.74^{* *}$ \\
\hline SCA $\times L$ & 105 & $81.03^{* *}$ & $4.85^{* *}$ & $8.24^{\text {NS }}$ & $392.47^{* *}$ & $24.44^{* *}$ \\
\hline ERROR & 176 & 51.32 & 0.60 & 7.35 & 5.19 & 0.84 \\
\hline CV $(\%)$ & & 5.03 & 7.70 & 5.04 & 2.30 & 4.40 \\
\hline$R^{2}$ & & 86.6 & 98.00 & 84.06 & 99.16 & 99.33 \\
\hline
\end{tabular}

DFO: days to flowering onset; NCB: number of clusters per branch; FW: Fruit weight; PA: Polar axis of the fruit, and Y: Yield. Ns. non-significant; ${ }^{*}$ and ${ }^{* *}$ indicate significant and highly significant values, respectively.

Similar results were found by Hernández et al. (2016) in three lines of Solanum lycopersicum, where additive effects were decisive for higher average yields. Therefore, parents with high averages for DFO, NCB, and $Y$ can be higher allele contributors in breeding programs for new varieties using hybridization methods or recurrent selection, where performance for a given characteristic could be verified with an F2 generation assessment (Rivera-Colín et al., 2019).

\section{General combining ability (GCA)}

Table 2 shows the effect of the GCA on five traits of agronomical interest in lulo for the 10 assessed parents. For the DFO, the additive effects accounted for $56.3 \%$ of the total sum of squares. Additionally, there were positive and significant values for parents 6 and 7 (3.75* and $3.86^{*}$, respectively) and a negative and significant effect for parental $8\left(-5.05^{* *}\right)$. Parental 8 is desirable because of an early onset of flowering and a higher capacity of transmission through all possible crosses; furthermore, the average of this parental was less than that of its hybrid combinations (García and Vallejo, 1990).

For the NCB, there were positive GCA effects from parents $1\left(0.60^{* *}\right)$ and $2\left(0.45^{*}\right)$, indicating their high transmission capacity for this trait through all possible crosses. Conversely, parental 4 had a negative and significant effect $\left(-0.74^{* *}\right)$, which demonstrated the below-average performance of its hybrid combinations (Tab. 2). This trait is important for several agronomical management tasks that aim to increase the production potential of plants. Accordingly, the recommended plants should have at least four to five productive branches to increase the number of extracategory and first-category fruits (Ardila et al., 2015).

Table 2. Effects of the general combining ability (GCA) on five agronomically important lulo traits in (S. quitoense) 10 assessed parents.

\begin{tabular}{|c|c|c|c|c|c|}
\hline PARENTS & DFO & NCB & PA & FW & $Y$ \\
\hline 1 & -1.92 & $0.60^{* *}$ & 0.08 & $-3.20^{* *}$ & -0.43 \\
\hline 2 & 2.63 & -0.23 & -0.65 & $-6.20^{* *}$ & $-0.97^{* *}$ \\
\hline 3 & 0.29 & -0.11 & $-1.31^{*}$ & -0.22 & $-0.88^{* *}$ \\
\hline 4 & -2.19 & $-0.74^{* *}$ & -0.68 & $2.26^{* *}$ & $0.66^{* *}$ \\
\hline 5 & -1.17 & 0.17 & 0.38 & 0.07 & 0.23 \\
\hline 6 & $3.75^{*}$ & -0.18 & 0.69 & $5.53^{* *}$ & $0.48^{*}$ \\
\hline 7 & $3.86^{*}$ & -0.17 & 1.27 & $3.07^{* *}$ & 0.02 \\
\hline 8 & $-5.05^{* *}$ & 0.36 & -0.30 & 0.01 & $1.08^{* *}$ \\
\hline 9 & 0.48 & -0.15 & 0.27 & -0.04 & 0.14 \\
\hline 10 & -0.68 & $0.45^{*}$ & 0.26 & $-1.28^{*}$ & -0.33 \\
\hline
\end{tabular}

DFO: Days to flowering onset; NCB: Number of clusters per branch; FW: Fruit weight; PA: Polar axis of the fruit, and Y: Yield. * and ${ }^{* *}$ indicate significant and highly significant values, respectively.

For the PA, no positive and significant GCA effects were found; however, parental 3 had a negative effect $\left(-1.31^{*}\right)$, indicating the below-average performance of its hybrid combinations. Lagos-Santander et al. (2019) and Lagos-Santander et al. (2020) reported positive and significant correlations of PA with FW 
and Y, meaning this variable was associated with traits related to the production potential of lulo. In this case, the FW had significant GCA effects in parents 4,6 , and $7\left(2.26^{* *}, 5.53^{* *}\right.$, and $3.07^{* *}$, respectively). On the other hand, for $Y$, the effects of parents $4\left(0.66^{* *}\right), 6\left(0.48^{*}\right)$, and $8\left(1.08^{* *}\right)$ indicated that they contributed to the parent-offspring transmission of this trait and that the additive effects were more relevant. Overall, these parents could be the most promising (Tab. 2).

\section{Specific combining ability (GCA)}

For the SCA effects (Tab. 3), the diallel cross design identified manifestations of the genetic dominance (Gardner and Eberhart, 1966). For the NCB, hybrids $1 \times 2,1 \times 5,1 \times 7,5 \times 10,6 \times 10$, and $8 \times 10$ had positive and significant SCA effects (Tab. 3), as well as significant averages that ranged from 11.37 to12.29 branches/plant (Tab. 4). The number of productive plants was used for formative pruning to increase

Table 3. Effects of the specific combining ability (SCA) on five agronomically important lulo traits (S. quitoense) assessed in a diallel cross of 10 parents (45 combinations).

\begin{tabular}{|c|c|c|c|c|c|}
\hline Hybrids & DFO & NCB & PA & FW & Y \\
\hline $1 \times 2$ & -1.21 & $1.00 * *$ & 0.03 & $5.72^{* *}$ & $-0.55^{*}$ \\
\hline $1 \times 3$ & -3.45 & $-0.83^{* *}$ & $-2.47^{* *}$ & $-3.25^{* *}$ & $0.70^{* *}$ \\
\hline $1 \times 4$ & 0.19 & 0.01 & -0.62 & $1.73^{* *}$ & $0.61^{* *}$ \\
\hline $1 \times 5$ & -1.16 & $1.10^{* *}$ & $2.21^{* *}$ & $1.80^{* *}$ & $2.31^{* *}$ \\
\hline $1 \times 6$ & 5.55 & $-1.64^{* *}$ & 0.21 & $-5.47^{* *}$ & $-0.94 * *$ \\
\hline $1 \times 7$ & -1.98 & $1.48 * *$ & -0.93 & $-4.51^{* *}$ & -0.13 \\
\hline $1 \times 8$ & 1.52 & 0.25 & -1.15 & $-4.15^{* *}$ & 0.11 \\
\hline $1 \times 9$ & -0.10 & $-0.67^{* *}$ & $1.39 * *$ & $7.51^{* *}$ & $-0.45^{*}$ \\
\hline $1 \times 10$ & 0.65 & $-0.72^{* *}$ & $1.34^{*}$ & 0.62 & $-1.66^{* *}$ \\
\hline $2 \times 3$ & 2.79 & 0.17 & 0.89 & $5.76^{* *}$ & $0.69 * *$ \\
\hline $2 \times 4$ & 0.72 & -0.07 & 0.11 & $-3.12^{* *}$ & $-0.88^{* *}$ \\
\hline $2 \times 5$ & 3.29 & -0.35 & -0.62 & $5.95^{* *}$ & $2.84 * *$ \\
\hline $2 \times 6$ & -3.84 & -0.30 & 0.10 & $-6.60^{* *}$ & $-0.60 * *$ \\
\hline $2 \times 7$ & -6.45 & $-1.39 * *$ & -0.36 & $-8.61^{* *}$ & $-1.28 * *$ \\
\hline $2 \times 8$ & -0.54 & $0.62^{* *}$ & $1.66^{*}$ & $6.34^{* *}$ & $1.16^{* *}$ \\
\hline $2 \times 9$ & 0.76 & 0.29 & -1.15 & $-9.27^{* *}$ & $-1.98^{* *}$ \\
\hline $2 \times 10$ & 4.47 & 0.03 & -0.66 & $3.84^{* *}$ & $0.58^{*}$ \\
\hline $3 \times 4$ & 3.52 & $0.59^{* *}$ & 0.09 & $-1.77^{* *}$ & $-2.54^{* *}$ \\
\hline $3 \times 5$ & 1.51 & $-0.56^{* *}$ & 0.41 & 0.39 & $2.22^{* *}$ \\
\hline $3 \times 6$ & -2.75 & $0.41^{*}$ & -0.49 & $-4.15^{* *}$ & $-1.44^{* *}$ \\
\hline $3 \times 7$ & 2.73 & 0.27 & $2.36^{* *}$ & $22.73^{* *}$ & $2.96^{* *}$ \\
\hline $3 \times 8$ & -2.32 & -0.21 & 0.60 & $-5.99 * *$ & $-1.26^{* *}$ \\
\hline $3 \times 9$ & -4.15 & 0.29 & $-1.62^{*}$ & $-6.93^{* *}$ & -0.42 \\
\hline $3 \times 10$ & 2.14 & -0.13 & 0.24 & $-6.78^{* *}$ & $-0.90^{* *}$ \\
\hline $4 \times 5$ & -1.68 & $0.44^{*}$ & 0.23 & $-5.45^{* *}$ & $-1.76^{* *}$ \\
\hline $4 \times 6$ & -3.73 & $0.62^{* *}$ & -0.63 & $-4.46^{* *}$ & 0.20 \\
\hline $4 \times 7$ & 3.58 & 0.24 & -0.22 & -0.48 & $1.78^{* *}$ \\
\hline $4 \times 8$ & 1.32 & $-1.62^{* *}$ & $1.65^{*}$ & $5.96 * *$ & 0.23 \\
\hline $4 \times 9$ & -0.13 & 0.17 & -1.03 & 0.33 & -0.20 \\
\hline
\end{tabular}


Table 3. Effects of the specific combining ability (SCA) on five agronomically important lulo traits (S. quitoense) assessed in a diallel cross of 10 parents (45 combinations).

\begin{tabular}{|c|c|c|c|c|c|}
\hline Hybrids & DFO & NCB & PA & FW & Y \\
\hline $4 \times 10$ & -3.80 & $-0.38^{*}$ & 0.40 & $7.26^{* *}$ & $2.56^{* *}$ \\
\hline $5 \times 6$ & 8.09 & $-1.12^{* *}$ & -0.36 & $24.70 * *$ & $-1.63^{* *}$ \\
\hline $5 \times 7$ & -1.48 & $0.46^{*}$ & 0.14 & $-5.33^{* *}$ & $-3.38^{* *}$ \\
\hline $5 \times 8$ & -0.90 & $-0.78^{* *}$ & $-2.48^{* *}$ & $-12.02^{* *}$ & $-0.77^{* *}$ \\
\hline $5 \times 9$ & -2.15 & $-0.82^{* *}$ & -0.50 & $-4.96^{* *}$ & $-0.58^{*}$ \\
\hline $5 \times 10$ & -5.52 & $1.63^{* *}$ & 0.97 & $-5.07^{* *}$ & $0.75^{* *}$ \\
\hline $6 \times 7$ & -4.53 & -0.16 & -0.67 & $-10.71 * *$ & 0.28 \\
\hline $6 \times 8$ & -4.37 & 0.32 & 0.41 & $7.09^{* *}$ & $3.51^{* *}$ \\
\hline $6 \times 9$ & 3.81 & $0.90^{* *}$ & 1.05 & $7.63^{* *}$ & $2.88^{* *}$ \\
\hline $6 \times 10$ & 1.77 & $0.97^{* *}$ & 0.38 & $-8.03^{* *}$ & $-2.25^{* *}$ \\
\hline $7 \times 8$ & 2.82 & $0.73^{* *}$ & 0.15 & -0.73 & $-0.76^{* *}$ \\
\hline $7 \times 9$ & 3.70 & -0.02 & 0.59 & $2.47^{* *}$ & -0.36 \\
\hline $7 \times 10$ & 1.62 & $-1.62^{* *}$ & -1.06 & $5.18^{* *}$ & $0.89^{* *}$ \\
\hline $8 \times 9$ & 1.03 & 0.16 & 1.02 & $1.87^{* *}$ & $-0.57^{*}$ \\
\hline $8 \times 10$ & 1.44 & $0.52 * *$ & $-1.85^{* *}$ & $1.63^{* *}$ & $-1.65^{* *}$ \\
\hline $9 \times 10$ & -2.76 & -0.31 & 0.25 & $1.35^{*}$ & $1.67^{* *}$ \\
\hline
\end{tabular}

DFO: Days to flowering onset; NCB: Number of clusters per branch; FW: Fruit weight; PA: Polar axis of the fruit, and Y: Yield. * and ** indicate significant and highly significant values, respectively.

the production potential of the plants by identifying branches with high vigor and an adequate number of floral clusters and flowers per cluster.

The hybrid combinations $1 \times 5,1 \times 9,1 \times 10$, and $3 \times 7$ had positive and significant SCA effects on the PA (Tab. 3), with averages ranging from $55.45 \mathrm{~m}(1 \times 10)$ to $56.45 \mathrm{~m}(1 \times 5)$ (Tab. 4). These hybrids were within caliber 35 and 30 according to norm NTC5093 (Icontec, 2002).

Significant SCA effects on the FW were found in $88.9 \%$ of the hybrid combinations (Tab. 3). Furthermore, $37.7 \%$ of these combinations exceeded the average weight $(100 \mathrm{~g})$, which is desirable for fruit commercialization (Muñoz, 2010). The hybrid combinations $3 \times 7,5 \times 6,6 \times 8$, and $6 \times 9$ had highly significant SCA effects $\left(22.73^{* *}, 24.70^{* *}, 7.09^{* *}\right.$, and $7.63^{* *}$, respectively) and averages that ranged from 111.55 to $124.51 \mathrm{~g}$ (Tab. 4).

The hybrid combinations had fruits with average weights (Tab. 4) that were above those reported by Lagos et al. (2015) (i.e., average fruit weight of $81.46 \pm 16.36 \mathrm{~g})$. These authors analyzed an initial population of 50 half-sibling lulo families to select those with improved fruit quality. The average weights in this study were also greater than the average weight of $97.29 \mathrm{~g}$ reported by Lagos-Santander $\mathrm{et}$ al. (2019), who assessed selected parents and hybrids based on performance characteristics. These authors, however, found weights up to $167 \mathrm{~g}$ in one hybrid and $148 \mathrm{~g}$ in a parent, demonstrating that FW interacts with the environment and its performance is associated with SCA effects that result from parental dominance, as reported here.

For the Y, significant SCA effects were found in $82 \%$ of the hybrid combinations, which demonstrated genetic dominance with respect to the parents. Combinations $1 \times 2,1 \times 9,5 \times 9$, and $8 \times 9$ had negative and significant effects, with below-average performance. Combinations $1 \times 5,2 \times 5,3 \times 7,4 \times 7,4 \times 8,4 \times 10$, $6 \times 9$, and $6 \times 8$ had positive values that reflected potential traits (Tab. 3).

Table 4 shows all the positive combinations with significant differences, including combination $6 \times 8$, which was highly significant. According to the biplot of the SCA effects on Y (Fig. 1), these significant 
combinations had performances above the SCA and the average yields of the other hybrid combinations (e.g., for $6 \times 8$, it was $25.96 \mathrm{t} \mathrm{ha}^{-1}$, as compared to $20.88 \mathrm{t} \mathrm{ha}^{-1}$ ). These results suggested that the parents of the best-performing crosses also had the best values for the SCA effects (parents 4, 6, and 8). When selecting for positive effects on desirable traits or negative effects to reduce undesirable traits, Guzmán et al. (2017) stated that a high GCA and SCA should be considered for the selection of parents or crosses.

The yield of all 45 hybrid combinations exceeded the average yield reported by Agronet (2020) for the Department of Nariño and Colombia in recent years (5.64 and $9.86 \mathrm{t} \mathrm{ha}^{-1}$, respectively). This finding must be analyzed considering commercial and experiment factors since, according to Sánchez et al. (2006), variations in plot size and shape and experiment units in an assay could generate results that differ from the normal performance of certain variables under commercial conditions. On the other hand, Beck et al. (1991) stated that, for yield, the dominant gene action is variable and can be influenced by the parents, environment, and their interaction. Lagos et al. (2015) reported yields ranging from 13.81 to $24.80 \mathrm{t} \mathrm{ha}^{-1}$ with plot sizes similar to those used here. Therefore, the results found in this study agree with previous reports and respond to the effect of the hybrid combinations assessed.

Table 4. Mean values of the variables assessed in 45 lulo hybrid combinations (S. quitoense) from a diallel cross of 10 parents in four municipalities in the Department of Nariño.

\begin{tabular}{|c|c|c|c|c|c|}
\hline CROSS & DF0 & NCB & FW & PA & Y \\
\hline $1 \times 2$ & 141.79 & $11.42^{*}$ & 95.24 & 53.24 & 18.94 \\
\hline $1 \times 3$ & $137.21^{*}$ & 9.71 & 92.26 & 50.07 & 20.28 \\
\hline $1 \times 4$ & 138.38 & 9.92 & 99.72 & 52.56 & 21.72 \\
\hline $1 \times 5$ & 138.04 & $11.92^{* *}$ & 97.59 & $56.45^{*}$ & $22.99^{*}$ \\
\hline $1 \times 6$ & 149.67 & 8.83 & 95.78 & 54.76 & 19.99 \\
\hline $1 \times 7$ & 142.25 & $11.96^{* *}$ & 94.29 & 54.20 & 20.34 \\
\hline $1 \times 8$ & $136.83^{*}$ & $11.25^{*}$ & 91.59 & 52.40 & 21.64 \\
\hline $1 \times 9$ & 140.75 & 9.83 & 103.19 & $55.51^{*}$ & 20.15 \\
\hline $1 \times 10$ & 140.33 & 10.38 & 95.07 & $55.45^{*}$ & 18.47 \\
\hline $2 \times 3$ & 148.00 & 9.88 & 98.28 & 52.70 & 19.72 \\
\hline $2 \times 4$ & 143.46 & 9.00 & 91.87 & 52.55 & 19.70 \\
\hline $2 \times 5$ & 147.04 & 9.63 & 98.75 & 52.89 & $22.98^{*}$ \\
\hline $2 \times 6$ & 144.83 & 9.33 & 91.66 & 53.91 & 19.80 \\
\hline $2 \times 7$ & 142.33 & 8.25 & 87.19 & 54.03 & 18.66 \\
\hline $2 \times 8$ & 139.33 & 10.79 & 99.08 & 54.48 & 22.16 \\
\hline $2 \times 9$ & 146.17 & 9.96 & 83.42 & 52.24 & 18.08 \\
\hline $2 \times 10$ & 148.71 & 10.29 & 95.29 & 52.72 & 20.17 \\
\hline $3 \times 4$ & 143.92 & 9.79 & 99.20 & 51.87 & 18.12 \\
\hline $3 \times 5$ & 142.92 & 9.54 & 99.17 & 53.25 & 22.45 \\
\hline $3 \times 6$ & 143.58 & 10.17 & 100.08 & 52.66 & 19.04 \\
\hline $3 \times 7$ & 149.17 & 10.04 & $124.51^{* *}$ & $56.09^{*}$ & $22.98^{*}$ \\
\hline $3 \times 8$ & $135.21^{*}$ & 10.08 & 92.73 & 52.76 & 19.83 \\
\hline $3 \times 9$ & 138.92 & 10.08 & 91.73 & 51.11 & 19.72 \\
\hline $3 \times 10$ & 144.04 & 10.26 & 90.65 & 52.96 & 18.78 \\
\hline $4 \times 5$ & $137.25^{*}$ & 9.92 & 95.81 & 53.71 & 20.01 \\
\hline $4 \times 6$ & 140.13 & 9.75 & 102.26 & 53.16 & 22.22 \\
\hline $4 \times 7$ & 147.54 & 9.38 & 103.78 & 54.14 & $23.34^{*}$ \\
\hline $4 \times 8$ & $136.38^{*}$ & 8.04 & 107.16 & 54.44 & $22.86^{*}$ \\
\hline $4 \times 9$ & 140.46 & 9.33 & 101.48 & 52.33 & 21.48 \\
\hline
\end{tabular}


Table 4, continuation.

\begin{tabular}{|c|c|c|c|c|c|}
\hline CROSS & DFO & NCB & FW & PA & Y \\
\hline $4 \times 10$ & $135.63^{*}$ & 9.37 & 107.17 & 53.75 & $23.78^{*}$ \\
\hline $5 \times 6$ & 152.96 & 8.92 & $129.23^{* *}$ & 54.49 & 19.96 \\
\hline $5 \times 7$ & 143.50 & 10.50 & 96.74 & $55.57^{*}$ & 17.75 \\
\hline $5 \times 8$ & $135.17^{*}$ & 9.79 & 86.99 & 51.37 & 21.42 \\
\hline $5 \times 9$ & 139.46 & 9.25 & 94.00 & 53.93 & 20.67 \\
\hline $5 \times 10$ & $134.92^{*}$ & $12.29 * *$ & 92.65 & $55.38^{*}$ & 21.54 \\
\hline $6 \times 7$ & 145.38 & 9.54 & 96.82 & 55.06 & 21.66 \\
\hline $6 \times 8$ & $136.63^{*}$ & 10.54 & $111.55^{*}$ & 54.57 & $25.96^{* *}$ \\
\hline $6 \times 9$ & 150.33 & 10.63 & $112.05^{*}$ & $55.78^{*}$ & $24.39 *$ \\
\hline $6 \times 10$ & 147.13 & $11.29^{*}$ & 95.15 & 55.10 & 18.79 \\
\hline $7 \times 8$ & 143.92 & 10.96 & 101.28 & 54.90 & 21.22 \\
\hline $7 \times 9$ & 150.33 & 9.71 & 104.43 & $55.90^{*}$ & 20.68 \\
\hline $7 \times 10$ & 147.08 & 8.71 & 105.90 & 54.24 & 21.47 \\
\hline $8 \times 9$ & 138.75 & 10.42 & 100.76 & 54.76 & 21.54 \\
\hline $8 \times 10$ & 138.00 & $11.37^{*}$ & 99.29 & 51.88 & 19.99 \\
\hline $9 \times 10$ & 139.33 & 10.04 & 98.96 & 54.54 & 22.37 \\
\hline$\mu$ & 142.29 & 10.05 & 98.93 & 53.77 & 20.88 \\
\hline$\sigma$ & 4.77 & 0.92 & 8.49 & 1.43 & 1.79 \\
\hline$\mu \pm \sigma$ & 137.52 & 10.97 & 107.42 & 55.21 & 22.68 \\
\hline$\mu \pm 2 \sigma$ & 132.76 & 11.89 & 115.90 & 56.64 & 24.47 \\
\hline
\end{tabular}

DFO: Days to flowering onset; NCB: Number of clusters per branch; FW: Fruit weight; PA: Polar axis of the fruit, and Y: Yield. ${ }^{*}$ and ${ }^{* *}$ indicate significant and highly significant values, respectively.

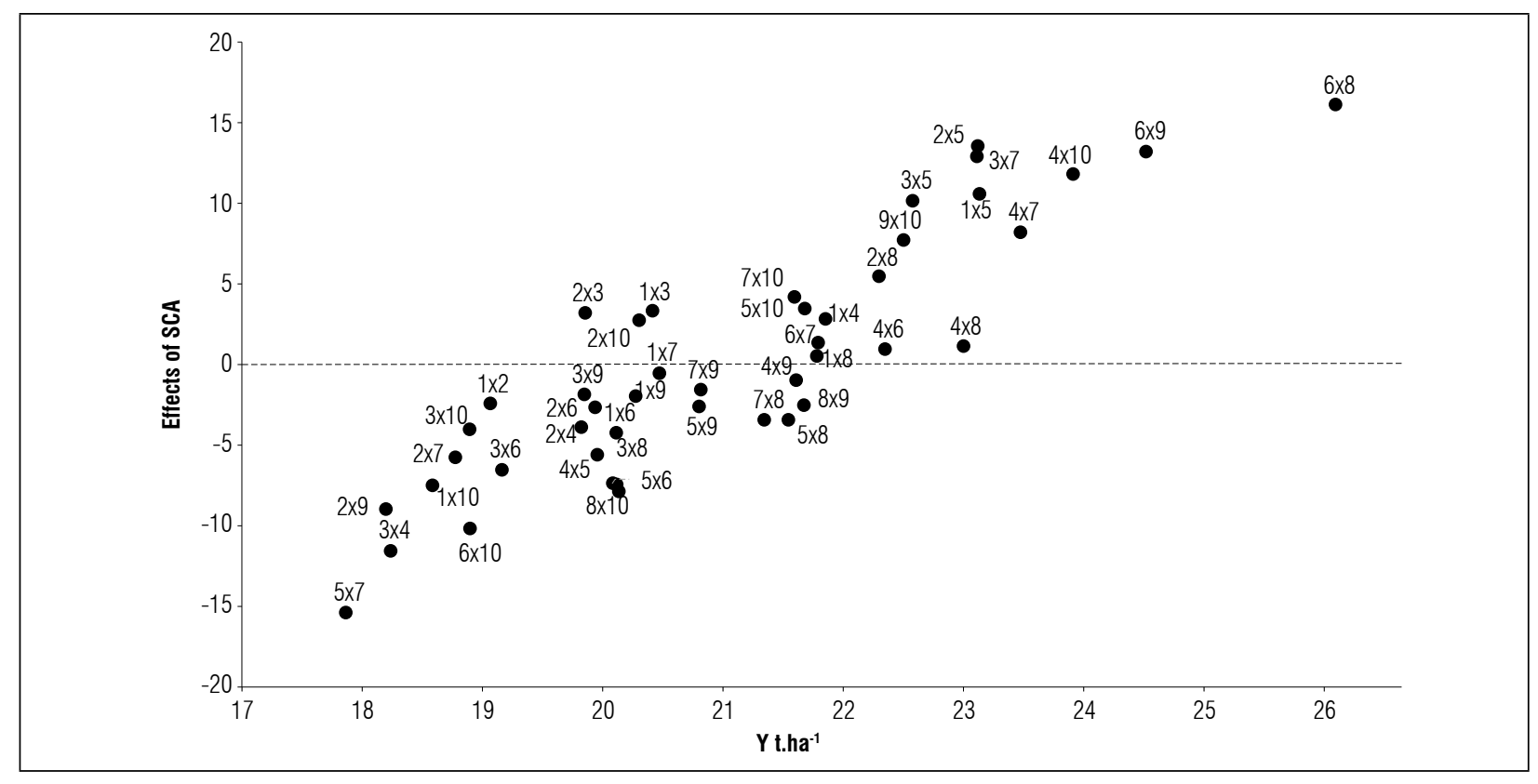

Figure 1. Biplot of the SCA effect on the yield of 45 lulo hybrid combinations (S. quitoense) from a diallel cross of 10 parents in four municipalities in the Department of Nariño. 


\section{CONCLUSION}

The effect of the locations on all assessed traits was variable. Furthermore, the interactions were significant for all cases, demonstrating that the genetic factors assessed here differentially responded to varying environmental conditions. The environment factor can affect the general selection of parents; therefore, local assessments are required to select adequate tools for improvement programs under specific environments.

Parents 4, 6, and 8 had desirable values for the GCA and positive values for the SCA regarding their hybrid combinations. Specifically, hybrid $6 \times 8$ had the best performance for the assessed hybrids. Moreover, combinations $4 \times 7,4 \times 8,4 \times 10$, and $6 \times 9$ had consistent performances in their environments, especially for the NCB and Y, indicating that these three parents are promising for the development of varieties and hybrids with potential production.

Conflict of interests: The manuscript was prepared and reviewed with the participation of the authors, who declare that there exists no conflict of interest that puts at risk the validity of the presented results.

\section{BIBLIOGRAPHIC REFERENCES}

Agronet. 2020. Estadísticas del sector agropecuario - lulo. In: https://www.agronet.gov.co/estadistica/Paginas/ home.aspx? cod=1; consulted: august, 2020.

Almanza-Merchán, P., J.D. Velandia, and Y.P. Tovar. 2017. Propiedades fisicoquímicas durante el crecimiento y desarrollo de frutos de lulo (Solanum quitoense Lam.). Rev. Colomb. Cienc. Hortíc. 10(2), 222-231. Doi: 10.17584/rcch.2016v10i2.5065

Antuna, O., F. Rincón, E. Gutiérrez del Rio, A. Ruiz, and L. Bustamante. 2003. Componentes genéticos de caracteres agronómicos y de calidad fisiológica de semillas de líneas de maíz. Rev. Fitotec. Mex. 26(1), 11-17.

Ardila, G., G. Fischer, and J.C. García. 2015. La poda de tallos y racimos florales afecta la producción de frutos de lulo (Solanum quitoense var. septentrionale). Rev. Colomb. Cienc. Hortic. 9(1), 24-37. Doi: 10.17584/ rcch.2015v9i1.3743

Beck, D., S.K. Vasal, and J. Crossa. 1991. Heterosis and combining ability among subtropical and temperate intermediate maturity maize germplasm. Crop Sci. 31, 68-73. Doi: https://doi.org/10.2135/ cropsci1991.0011183X002600010017x

Cruz, C.D. 1998. Programa GENES - Aplicativo computacional em estatística aplicada à genética (GENES - Software for Experimental Statistics in Genetics). Genet. Mol. Biol. 21(1). Doi: 10.1590/S1415-47571998000100022

Camposeco, N., V. Robledo, L. Valdez, F. Ramírez, R. Mendoza, and A. Mendoza. 2015. Estimación de la aptitud combinatoria en poblaciones de tomate de cáscara. Rev. Mex. Cienc. Agríc. 6(3), 437-451. Doi: 10.29312/ remexca.v6i3.630

Cardona, W., L. Bautista, N. Flórez, and G. Fischer. 2016. Desarrollo de la biomasa y raíz en plantas de lulo (Solanum quitoense var. Septentrionale) en respuesta al sombrío y anegamiento. Rev. Colomb. Cienc. Hortic. 10(1), 53-65. Doi: 10.17584/rcch.2016v10i1.5124

Cervantes-Ortiz, F., A. García-De los Santos, C. Carballo, J. Bergvinson, M. Crossa, E. Mendoza, E. Andrio, R. Rivera, and M. Moreno. 2011. Estimación de efectos genéticos relacionados con el vigor de la semilla y de la plántula en maíces tropicales mexicanos. Phyton 80 , 19-26. Doi: 10.32604/phyton.2011.80.019

Cervantes-Ortiz, F., J. Hernández-Esparza, J.A. Rangel-Lucio, E. Andrio-Enríquez, M. Mendoza-Elos, and G. Rodríguez-Pérez. 2016. Aptitud combinatoria general y específica en la calidad de semilla de líneas S3 de maíz. Rev. Fit. Mex. 39(3), 259-268. Doi: 10.35196/ rfm.2016.3.259-268

Criollo-Escobar, H., M.-F. Moncayo-Palacios, and T.C. Lagos-Burbano. 2020. Phenology and growth of lulo (Solanum quitoense Lam.) plants grafted onto Solanum hirtum Vahl. Rev. Colomb. Cienc. Hortíc. 14(3). Doi: 10.17584/rcch.2020v14i3.11005

De la Cruz, L., G. Castañón, N. Brito, A. Gómez, V. Robledo, and A. Lozano. 2010. Heterosis y aptitud combinatoria de poblaciones de maíz tropical. Rev. Int. Bot. Exp. 79, 11-17.

De la Cruz, L.E., V.A. Gómez, B.A. López, O.R. Osorio, G.A. Palomo, T.V. Robledo, and H.S. Rodríguez. 2007. Aptitud combinatoria de líneas de maíz de alta calidad de proteína para características forrajeras. Univ. Cienc. 23(1), 57-68.

De la Rosa, A., H. De León, G. Martínes, and F. Rincón. 2000. Heterosis, habilidad combinatoria y diversidad genética en híbridos comerciales de maíz (Zea mays L.). Agron. Mesoam. 11(1), 113-122. Doi: 10.15517/ am.v11i1.17360

Escorcia-Gutiérrez, N., J.D. Molina-Galán, F. Castillo-González, and J.A. Mejía-Contreras. 2010. Rendimiento, heterosis y depresión endogámica de cruzas simples de maíz. Rev. Fitotec. Mex. 33:271-279. Doi: 10.35196/ rfm.2010.3.271

García, A. and F.A. Vallejo. 1990. Habilidad combinatoria para el carácter producción por planta y sus componentes primarios en un cruzamiento dialelico de siete líneas de tomate "Chonto" Lycopersicun esculemtum, Mill. Acta Agronom. 40(1-2), 32-41.

Gardner, C.O. and S.A. Eberhart. 1966. Analysis and interpretation of the variety cross diallel and related population. Biometrics 22, 439-452. Doi: 10.2307/2528181 
Guerrero-Guerrero, C., A. Espinoza-Banda, A. Palomo-Gil, E. Gutiérrez-del Río, H. Zermeño-González, and M. González-Castillo. 2011. Aptitud combinatoria del rendimiento y sus componentes en dos grupos de líneas de maíz. Agron. Mesoam. 22(2), 257-267.

Griffing, B. 1956. Concepts of general and specific combining ability in relation to diallel crossing systems. Aust. J. Biol. Sci. 9, 463-493. Doi: 10.1071/BI9560463

Guzmán, M., D. Díaz, C. Ramis, R. Figueroa-Ruiz, and R. Jiménez. 2017. Estimación de la aptitud combinatoria y heterosis en híbridos no convencionales de maíz con alto contenido de proteína. Bioagro 29(3), 175-184.

Haochuan, L., T. Jihua, H. Yanmin, Y. Jiwey, and L. Zonghua. 2014. Analysis on combining ability and estimation of genetic parameters for chlorophyll content in maize. J. Plant Breed. Crop Sci. 6(8), 97-104. Doi: 10.5897/JPBCS2013.0435

ICONTEC, Instituto Colombiano de Normas Técnicas y Certificación. 2002. Norma Técnica Colombiana, NTC 5093. Frutas frescas. Lulo de Castilla. Especificaciones. Bogota, DC.

Lagos, T.C., J. Apraez, L. Lagos, and D. Duarte. 2015. Comportamiento de 50 familias de medios hermanos de Solanum quitoense Lam. bajo selección recurrente. Temas Agrar. 20(2), 19-29. Doi: 10.21897/rta.v20i2.755

Lagos, T., F. Vallejo, and H. Criollo. 2007. Análisis de la aptitud combinatoria de algunas características del fruto de Physalis peruviana L. Agron. Colomb. 25(1), 36-46.

Lagos-Santander, L., T. Lagos-Burbano, D. Duarte-Alvarado, H. Criollo-Escobar, and N. Angulo-Ramos. 2019. Evaluación del rendimiento y calidad de fruto de parentales e híbridos de lulo de Castilla. Rev. UDCA Actual. Divulg. Cient. 22(2), e1344. Doi: 10.31910/rudca. v22.n2.2019.1344

Lagos-Santander, L., F.A. Vallejo, T. Lagos-Burbano, and D. Duarte-Alvarado. 2020. Evaluación agronómica de familias de medios hermanos de lulo de Castilla, Solanum quitoense Lam. Rev. UDCA Actual. Divulg. Cient. 23(1), e1334. Doi: 10.31910/rudca.v23.n1.2020.1334

Luna, O.J., J.L.H. García, R.D.C. Valdés, M.A.R. Gallegos, P.R. Preciado, C.G. Guerrero. 2013. Aptitud combinatoria y sus componentes genéticos en líneas de maíz. Univ. Cienc. 29(3), 243-253.

Manjarrez, M., F. Palemón, N. Gómez, A. Espinosa, S. Rodríguez, A. Damián, and B. Cruz. 2014. Aptitud combinatoria general y específica de maíces normales y de alta calidad de proteína. Rev. Mex. Cienc. Agríc. 5(7), 1261-1273. Doi: 10.29312/remexca.v5i7.870

Hernández, R., A. López, J. Espinoza, D. Sánchez, C. Reyes, G. Rojas, and F. Gordillo. 2016. Potencial genético y heterosis para rendimiento en líneas de tomate (Solanum lycopersicum L.). Rev. Mex. Cienc. Agríc. 7(2), 349-362.

Medina, C., M. Lobo, and E. Martínez. 2009. Revisión del estado del conocimiento sobre la función productiva del lulo (Solanum quitoense Lam.) en Colombia.
Corpoica Cienc. Tecnol. Agropecu. 10(2), 167-179. Doi: 10.21930/rcta.vol10_num2_art:139

Morillo, A., A. Rodríguez, and Y. Morillo. 2019. Caracterización morfológica de lulo (Solanum quitoense Lam.) en el municipio de Pachavita, Boyacá. Acta Biol. Colomb. 24(2), 291-298. Doi: 10.15446/abc.v24n2.75832

Morillo-Coronado, A.C., A.P. Rodríguez Fagua, and Y. Mori1lo-Coronado. 2017. Characterization of lulo (Solanum quitoense Lam.) genetic diversity in the department of Boyaca, Colombia. Acta Agron. 66(3), 430-435. Doi: 10.15446/acag.v66n3.58997

Muñoz, L. 2010. Evaluación agronómica de materiales de lulo Solanum sp., frutal de alto potencial para zonas tropicales. MSc thesis. Universidad Nacional de Colombia, Palmira, Colombia.

Ochoa-Vargas, L.M., H.E. Balaguera-López, G. Ardila-Roa, E.H. Pinzón-Sandoval, and J.G. Álvarez-Herrera. 2016. Crecimiento y desarrollo del fruto de lulo (Solanum quitoense Lam.) en el municipio de San Antonio del Tequendama (Colombia). Corpoica Cienc. Tecnol. Agropecu. 17(3), 347-359. Doi: 10.21930/rcta. vol17_num3_art:512

Ortiz, J.R. and P.C. Rodes. 1993. Habilidad combinatoria de 8 líneas élites dominicanas de maíz (Zea mays L.). Agron. Mesoam. 4, 65-70. Doi: 10.15517/ am.v4i0.25169

Rivera-Colín, A., J. Mejía-Carranza, L. Vázquez-García, E. Urbina-Sánchez, and M. Ramírez-Gerardo. 2019. Aptitud combinatoria y heterosis en variedades de gerbera (Gerbera $\times$ hybrida). Rev. Fitotec. Mex. 42(2), 155-162. Doi: 10.35196/rfm.2019.2.155-162

Sánchez, M., A. Mejía, C. Villanueva, J. Castellanos, C. Sánchez, and C. Jiménez. 2006. Determinación del tamaño adecuado de parcela experimental en calabaza pipiana (Cucurbita argyrosperma Huber var. stenosperma). Rev. Fitotec. Mex. 29(4), 339-348.

Sánchez-Reinoso, A.D., Y. Jiménez-Pulido, J.P. Martínez-Pérez, C.S. Pinilla, and G. Fischer 2019. Parámetros de fluorescencia de la clorofila y otros parámetros fisiológicos como indicadores del estrés por anegamiento y sombrío en plántulas de lulo (Solanum quitoense var. septentrionale). Rev. Colomb. Cienc. Hortic. 13(3), 325335. Doi: 10.17584/rcch.2019v13i3.10017

Sprague, G.F. and A. Tatum. 1942. General vs. specific combining ability in single crosses of corn. J. Am. Soc. Agron. 34, 923-932. Doi: 10.2134/agronj1942.000219 $62003400100008 \mathrm{x}$

Vivek, B.S., O. Odongo, J. Njuguna, J. Imanywoha, G. Bigirwa, A. Diallo, and K. Pixley. 2010. Diallel analysis of grain yield and resistance to seven diseases of 12 African maize (Zea mays L.) inbred lines. Euphytica 172, 329-340. Doi: 10.1007/s10681-009-9993-5

Wong, R., E. Gutiérrez, A. Palomo, S. Rodríguez, H. Córdova, A. Espinoza, and J.J. Lozano. 2007. Aptitud combinatoria de componentes del rendimiento en líneas de maíz para grano en la comarca lagunera, México. Rev. Fitotec. Mex. 30(2), 181-189. 